\author{
E-ISSN: 2321-9637 \\ Available online at www.ijrat.org
}

\title{
Analysis of Multi-Storey Building in Different Seismic Zones of India
}

\author{
UmamaheswaraRao Tallapalem $^{1}$, Nurulla Shaik ${ }^{2}$, Gopi Pagidimarry ${ }^{3}$ \\ Department of civil engineering,Nalanda Institute of Engineering and Technology, sattenapalli,AP, India ${ }^{1,2,3}$ \\ Email: umamaheswararaotallapalem@gmail.com ${ }^{1}$, nurushaik9676@yahoo.com ${ }^{2}$, gopip887@ gmail.com ${ }^{3}$
}

\begin{abstract}
Todays world facing some of the major problems causing by the nature.One of the major natural disaster is the Earthquake.We never know the Direction of the attack and magnitude of the Earthquake,so it will be the challenge the science and Technology.Past few years research done on the various issues of Earthquake.Now a Days people lives in Multi-storey Buildings such case when Earthquake hit the populated areas it will be cause huge loss of Damage.Hence Earthquake analysis get importance to analyse the structure safe against the collapse and Design the structure to safe against Earthquake occur during the life time of the structure.In this study model a G+7 Structure in staadPro and analysed the Earthquake analysis of the Structure in Different seismic zones(II,III,IV,V) of india.The present study gives Base shear,Floor Displacements,support Reactions and variation of steel quantity from zone to zone.In this study fill the void of IS:1893-2002 doesn't provide the variations steel quantity from zone to zone.In this study consider the all basic parameters of earthquake effected Multi-storey building and analysed with Different Load combinations.
\end{abstract}

Index terms: Base shear, Deflection, Floor Displacement, Seismic zones, support reactions.

\section{INTRODUCTION}

\section{Earthquakes:}

The earth Shape is spheroid and it consists of the three layers such as crust,mantle and core. The earthquakes are occur in the crust layer only,crust layer dived into two parts Lithosphere and asthenosphere. Lithosphere is a rigid plate and it can be divide into seven major parts and several minor parts.Asthenosphere is a semi rigid part and Lithosphere is float on the Asthenosphere, Because of the convection currents plates of Lithosphere plates are movements takes place, when two plates are hit each other the large amount of energy is released in the form of waves. The waves are hit the earth surface in the form of vibrations that vibrations lead to Earthquakes.Eartquake vibrations are formed at the point of initiation of rupture to in all directions in the form of elastic waves, ,these waves are mainly divide into primary waves or $\mathrm{p}$ waves, secondry waves or $\mathrm{s}$ waves and surface waves. Generally Earthquakes are formed due to the rupture in the plates, where rupture takes place that is place for origin of the earthquake that place is called as the focus or Hypocenter. The place just above the earth surface is called as the Epicenter.The Distance from focus to Epicentre is known as the focal depth. Earthquake size can be determined by both magnitude and Intensity,magnitude means the amount of Energy is released during the rupture takes place.Intensity means the amount of Damaged occur due the Earthquake. Finally we never find out the where will be the earthquake occur and size of the of the earthquake,once Earthquake hit the populated areas it would be huge loss.So Analyse the structures based on the location of the structure and consider the all components.Desin the structure to resist the Earthquake. Mahmoud,SY[1] analysed 14 Storey flat slab-column building with shear wall system and conclude that Static analysis gives higher values for maximum Displacements of the stories rather than Dynamic RS method. RizawanSultan,M[2] he conclude that Irregular Buildings are severely effected to Earthquakes in Higher seismic zones specially c shaped. structures are vulnerable compare to all other Different shapes.Saikrishna,T.[3] analysed the G+7 Multistorey Building and Give the variations of the steel quantity from zone to zone. Venkatarao[4] it was reported has structure with shearwall at the corners is to be a better alternative for Building in Earthquake prone area. Satyanarayana,K[5] he replays that the Building with soft storey have more Lateral Displacement and it is the weak spot to Bhandarkr,R.[6] Studied the G+7 Structure and conclude that performance of Shear structure is better 
International Journal of Research in Advent Technology, Vol.7, No.5, May 2019

E-ISSN: 2321-9637

Available online at www.ijrat.org

than the framed structure. Arvindkumar,G.[7] Observe that same Building Designed in seismic zone II,III,IV and $\mathrm{V}$ become expensive due to increase the Horizantal seismic forces and Increase in column moments. Pawade,c.[8]he observed that Irregular buildings are more vulnerable to the seismic effect. sylviya,B [9] It is observed that the shear walls should be provide throughout the height of building for best Earthquake performance,he conclude that shear walls are are placed at periphery of the Building is most effective.

\section{EARTHQUAKE ANALYSIS}

\section{A. General introduction}

In this study find out the variation of response of the multi-storey building in different seismic zones for that study consider a $\mathrm{G}+7$ structure with proper Dimensions of structural elements. Analyse the Structure in Staad.Pro in all seismic zones and compare the results of Base shear, Floor Displacements, support Reactions and variation of steel quantity and Quantify the results of analysed structure.

\section{B. Modal Generation}

Proposed model is Generated in the staad.pro software and analysed.

Table 1. Load calculation of proposed model

\begin{tabular}{|c|c|}
\hline Size of the beam & $0.6 \mathrm{~m} \times 0.35 \mathrm{~m}$ \\
\hline Size of the column & $0.45 \mathrm{~m} \times 0.45 \mathrm{~m}$ \\
\hline Slab thickness & $150 \mathrm{~mm}$ \\
\hline Height of floor & $3 \mathrm{~m}$ \\
\hline Exterior wall & $350 \mathrm{~mm}$ \\
\hline Interior wall & $200 \mathrm{~mm}$ \\
\hline Parapet wall & $100 \mathrm{~mm}$ \\
\hline $\begin{array}{c}\text { Load Details: } \\
\text { Dead Loads }\end{array}$ & $\begin{array}{c}0.35 \times 2.55 \times 20 \\
=17.85 \mathrm{KN} / \mathrm{m}\end{array}$ \\
\hline $\begin{array}{c}\text { Self weight of exterior } \\
\text { wall }\end{array}$ & $\begin{array}{c}0.2 \times 2.55 \times 20 \\
10.2 \mathrm{KN} / \mathrm{m}\end{array}$ \\
\hline $\begin{array}{c}\text { Self weight of partition } \\
\text { wall }\end{array}$ & $\begin{array}{c}0.1 \times 1 \times 20 \\
=2 \mathrm{KN} / \mathrm{m}\end{array}$ \\
\hline $\begin{array}{c}\text { Self weight of parapet } \\
\text { wall }\end{array}$ & $\begin{array}{c}0.02 \times 2.55 \times 18 \times 2 \\
=1.84 \mathrm{KN} / \mathrm{m}\end{array}$ \\
\hline $\begin{array}{c}\text { Plastering } \\
\text { Total self weight of } \\
\text { Exterior wall }\end{array}$ & $19.69 \mathrm{KN} / \mathrm{m}$ \\
\hline
\end{tabular}

\begin{tabular}{|l|l|}
\hline $\begin{array}{l}\text { Total self weight of Interior } \\
\text { wall }\end{array}$ & $\begin{array}{l}10.2+1.84 \\
=\end{array}$ \\
\hline $\begin{array}{l}\text { Total self weight of Parapet } \\
\text { wall }\end{array}$ & \begin{tabular}{l}
$2+04 \mathrm{KN} / \mathrm{m}$ \\
\hline Live Loads
\end{tabular} \\
\hline Floor Load & $2 \mathrm{KN} / \mathrm{m}^{2}$ \\
\hline Roof Load & \\
\hline
\end{tabular}

Figure 1. Plan of proposed structure

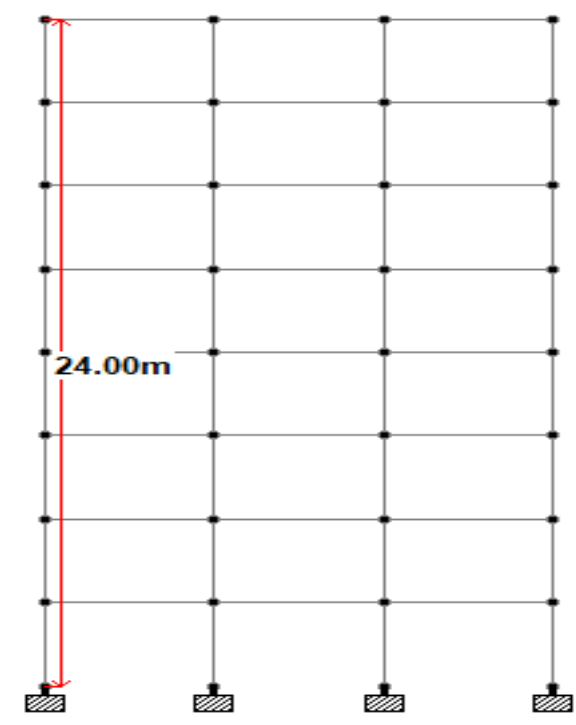

Figure 2. Elevation of proposed structure 
International Journal of Research in Advent Technology, Vol.7, No.5, May 2019

E-ISSN: 2321-9637

Available online at www.ijrat.org

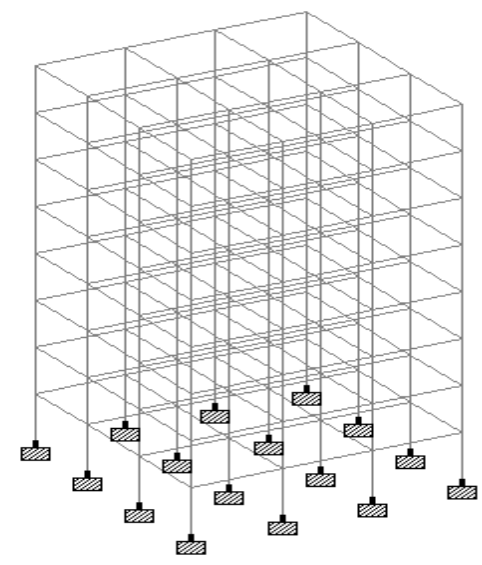

Figure 3. Isometric view of proposed structure

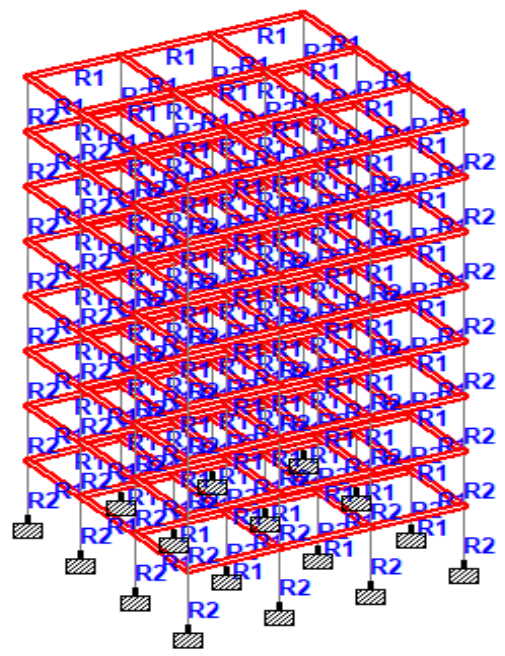

Figure 4. Assigning of Beam Elements

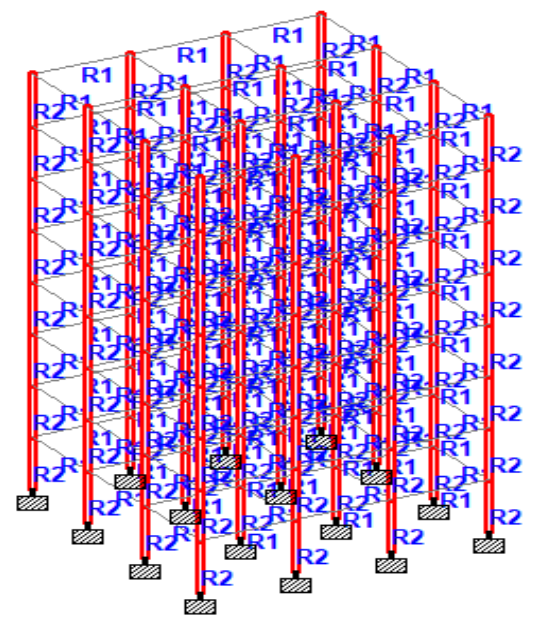

Figure 5. Assigning of Column Elements

\section{Assigning of Loads}

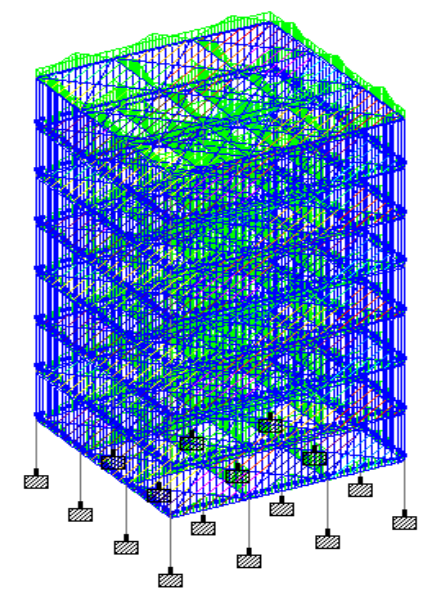

Figure 6.Assigning of Exterior Wall Load $(19.69 \mathrm{KN} / \mathrm{m})$

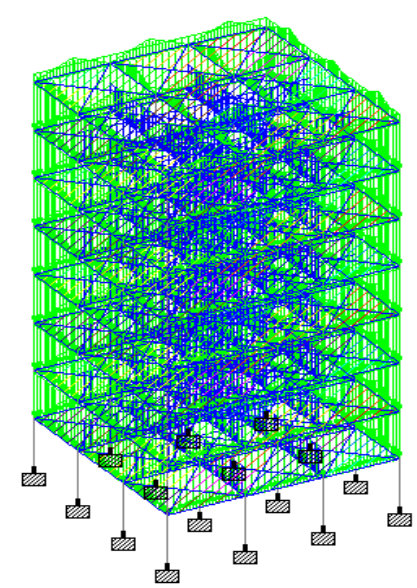

Figure 7.Assining of Interior Wall Load (12.04KN/m)

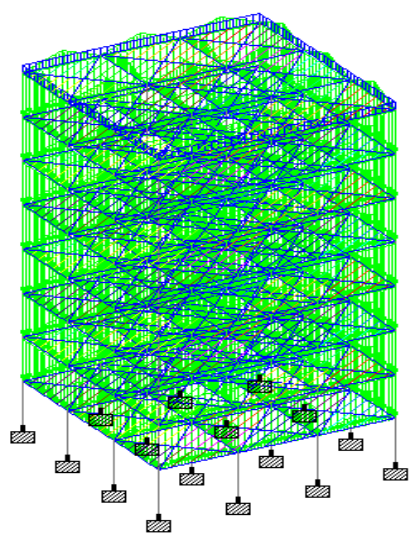

Figure 8.Assining of Parapet Wall Load Load $(3.84 \mathrm{KN} / \mathrm{m})$ 


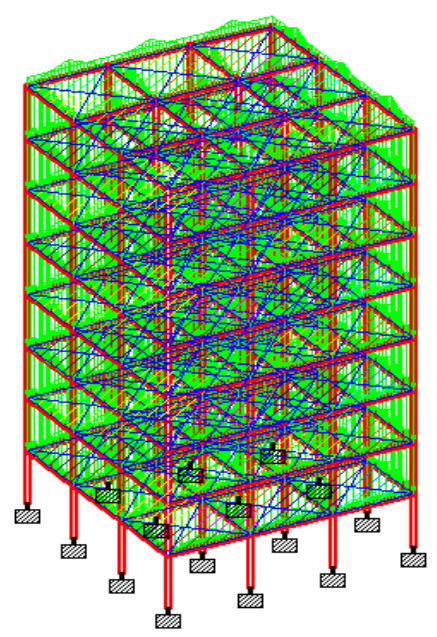

Figure 9.Assining of Self weight

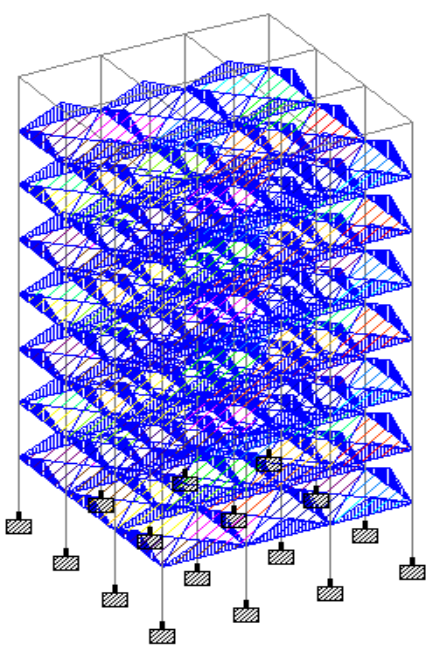

Figure 10.Assining of Floor Load $\left(4 \mathrm{KN} / \mathrm{m}^{2}\right)$

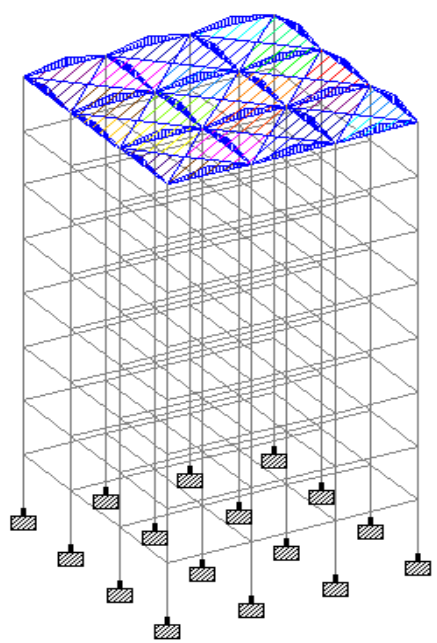

Figure 11.Assining of Roof Load $\left(2 \mathrm{KN} / \mathrm{m}^{2}\right)$

\section{RESULTS AND ANALYSIS}

\section{A. Base Shear:}

Base Shear is the amount of external Lteral force acting on the base of the structure due to the earthquake,that external force is transmitted to the top floors because of the fixed nature of the supports that transmitted external force will be the cause to the floor displacements. The newly developed displacements may cause to failure of structure so that is the importance to the Base shear.So we Estimate the amount of Base shear acting on the floors and variation of Base shear from floor to floor and include the zone to zone variation. Mention the Details of the of the graph details in table format is just bellow the graph for better understand the behaviour the structure due to earthquake effect.

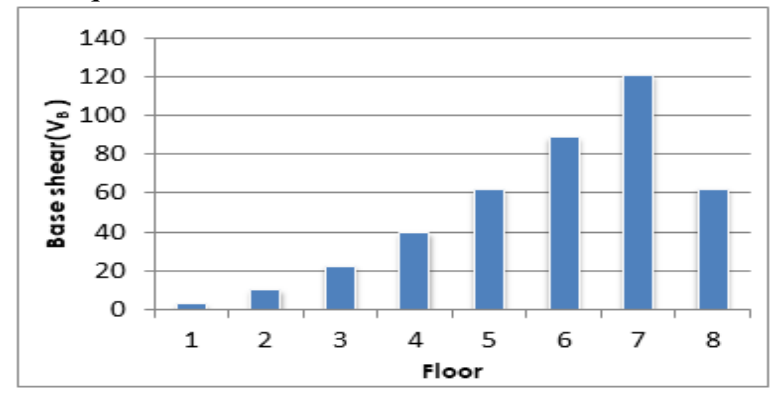

\begin{tabular}{|l|c|c|c|c|c|c|c|c|}
\hline Floor & 1 & 2 & 3 & 4 & 5 & 6 & 7 & 8 \\
\hline $\begin{array}{l}\text { Base } \\
\text { Shear(KN) }\end{array}$ & 2.46 & 9.8 & 22.15 & 39.37 & 61.51 & 88.58 & 120.57 & 62 \\
\hline
\end{tabular}

Figure 12. Floor - Base Shear Graph for Zone-II

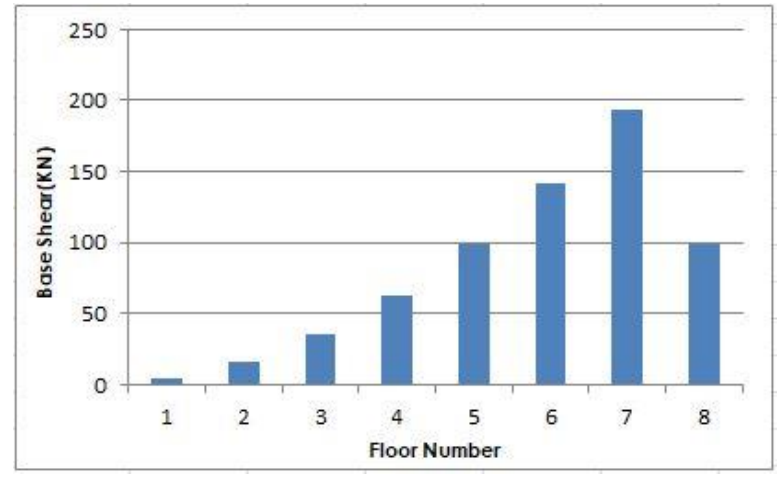

\begin{tabular}{|l|c|c|c|c|c|c|c|c|}
\hline Floor Number & 1 & 2 & 3 & 4 & 5 & 6 & 7 & 8 \\
\hline Base shear[Kn) & 3.94 & 15.75 & 35.43 & 62.99 & 98.42 & 141.73 & 192.91 & 99.33 \\
\hline
\end{tabular}

Figure 13. Floor - Base Shear Graph For Zone-III 
International Journal of Research in Advent Technology, Vol.7, No.5, May 2019

E-ISSN: 2321-9637

Available online at www.ijrat.org

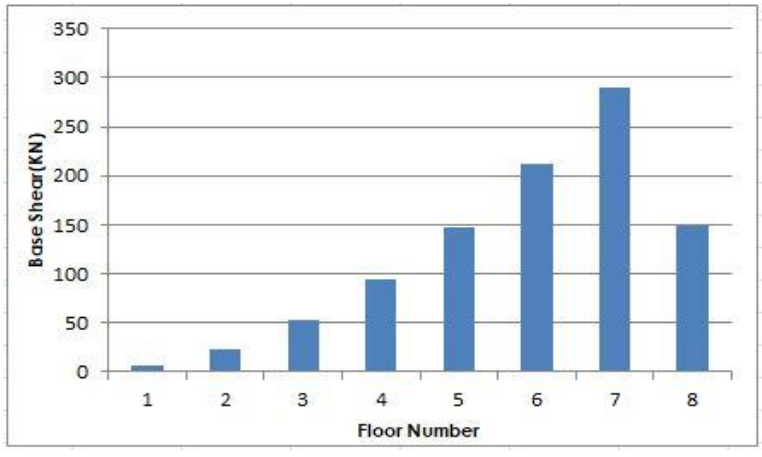

\begin{tabular}{|l|c|c|c|c|c|c|c|c|}
\hline Floor Number & 1 & 2 & 3 & 4 & 5 & 6 & 7 & 8 \\
\hline Base shear|(Kn) & 5.91 & 23.62 & 53.15 & 94.49 & 147.63 & 212.59 & 289.36 & 149 \\
\hline
\end{tabular}

Figure 13. Floor - Base Shear Graph For Zone-IV

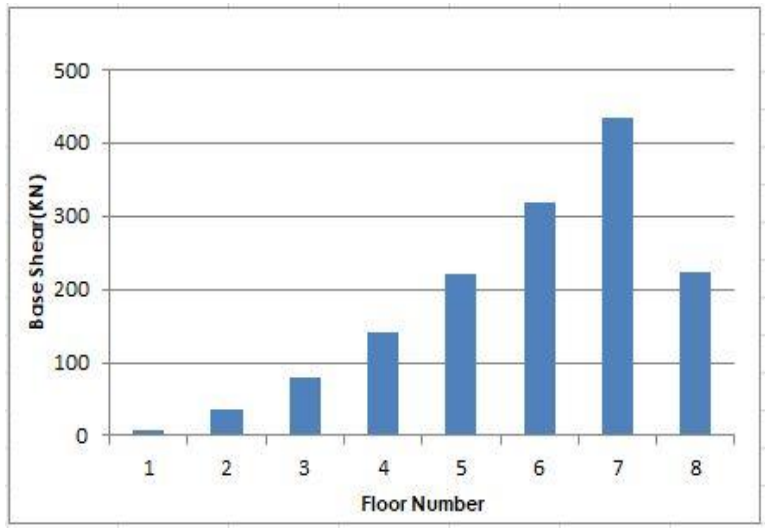

\begin{tabular}{|l|c|c|c|c|c|c|c|c|}
\hline Floor Number & 1 & 2 & 3 & 4 & 5 & 6 & 7 & 8 \\
\hline Base shear|Kn) & 8.86 & 35.43 & 79.72 & 141.73 & 221.45 & 318.89 & 434.04 & 223.5 \\
\hline
\end{tabular}

Figure 14. Floor - Base Shear Graph For Zone-v

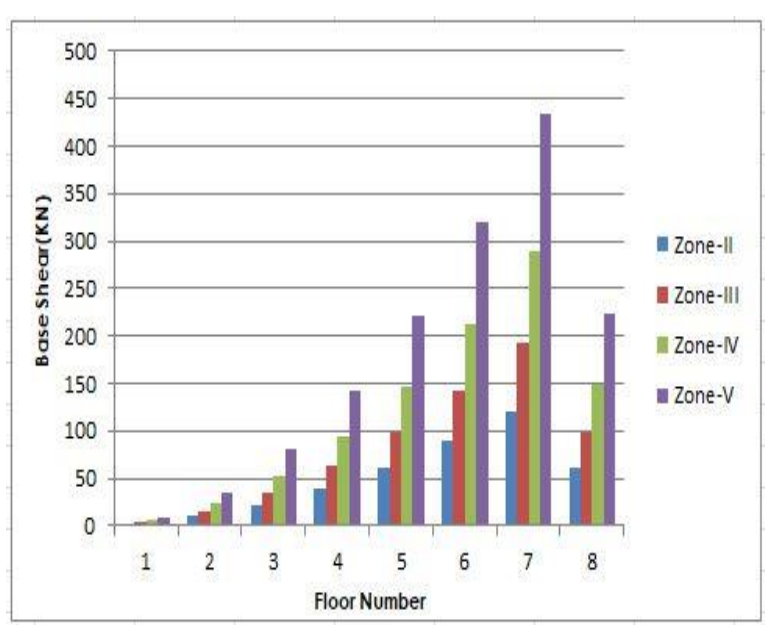

Figure 15.Comparasion of Base Shear in Different seismic zones

\section{B. Floor Displacements:}

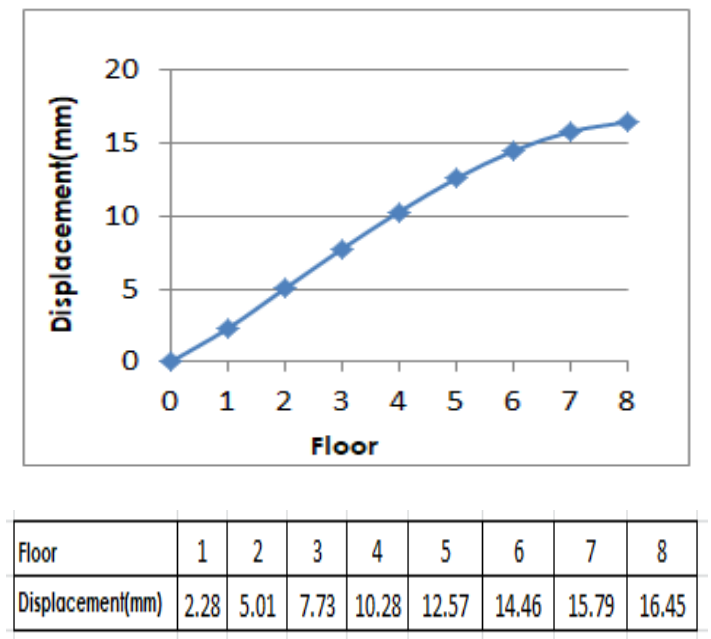

Figure 16.Floor - Displacement curve for Zone-II

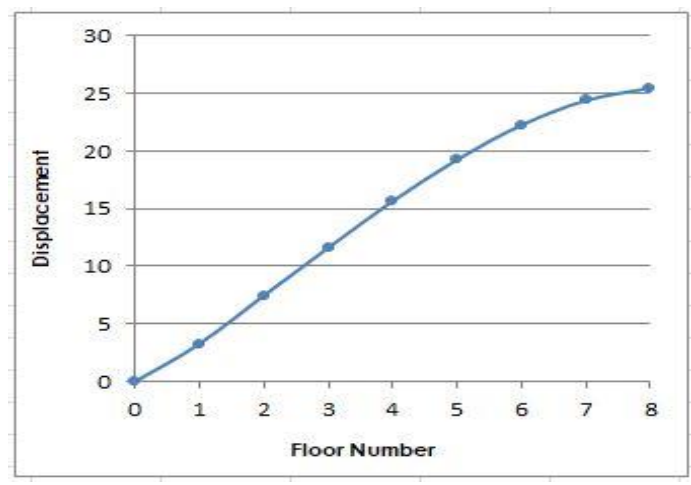

\begin{tabular}{|l|c|c|c|c|c|c|c|c|}
\hline Floor Number & 1 & 2 & 3 & 4 & 5 & 6 & 7 & 8 \\
\hline Displacement(mm) & 3.28 & 7.47 & 11.62 & 15.66 & 19.26 & 22.26 & 24.39 & 25.47 \\
\hline
\end{tabular}

Figure17.Floor - Displacement curve for Zone-III

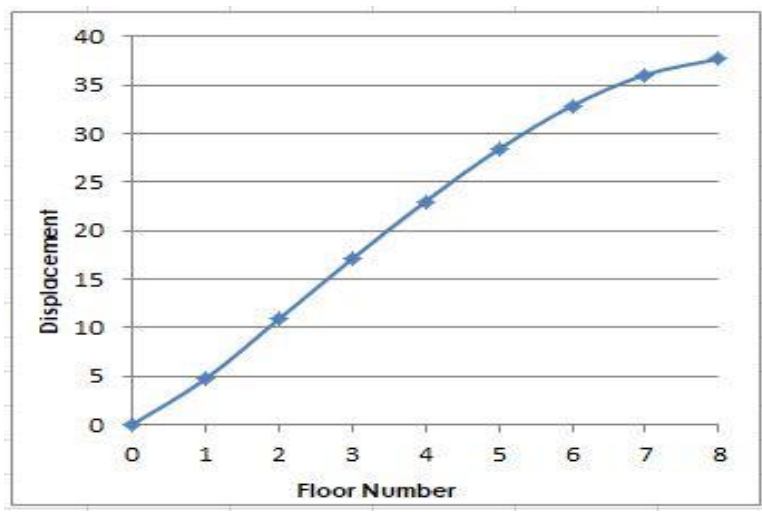

\begin{tabular}{|l|c|c|c|c|c|c|c|c|}
\hline Floor Number & 1 & 2 & 3 & 4 & 5 & 6 & 7 & 8 \\
\hline Displacement(mm) & 4.69 & 10.87 & 17.08 & 23.02 & 28.39 & 32.88 & 36.08 & 37.72 \\
\hline
\end{tabular}

Figure18.Floor - Displacement curve for Zone-IV 
International Journal of Research in Advent Technology, Vol.7, No.5, May 2019

E-ISSN: 2321-9637

Available online at www.ijrat.org

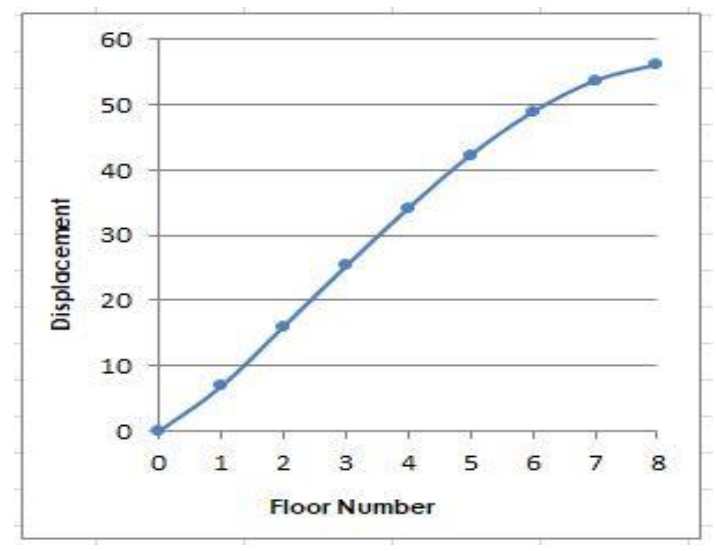

\begin{tabular}{|l|c|c|c|c|c|c|c|c|}
\hline Floor Number & 1 & 2 & 3 & 4 & 5 & 6 & 7 & 8 \\
\hline Displacement(mm) & 6.87 & 16.05 & 25.31 & 34.18 & 42.33 & 48.94 & 53.74 & 56.24 \\
\hline
\end{tabular}

Figure19.Floor - Displacement curve for Zone-V

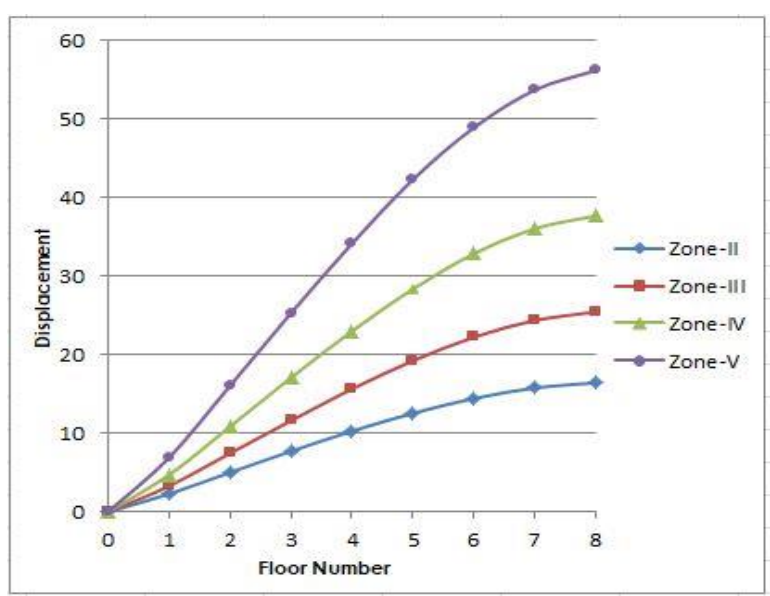

Figure20.Floor - Displacement for Different seismic zones

\section{Support Reactions:}

From the analysed results of support Reactions for Different supports are Divided into three Groups Groups based on the values. This Grouping helps to design of foundation of the Building from the Bellow Table is explain the variation of support reactions in Different seismic zones of India.
Table 2. Support reactions for proposed structure

\begin{tabular}{|c|c|c|c|c|c|}
\hline Group & Joint & ZONE-II & ZONE-III & ZONE-IV & ZONE-V \\
\hline \multirow{4}{*}{ Group-1 } & 1 & \multirow{4}{*}{1946.08} & \multirow{4}{*}{2059.64} & \multirow{4}{*}{2222.9} & \multirow{4}{*}{2467.79} \\
\hline & 4 & & & & \\
\hline & 109 & & & & \\
\hline & 112 & & & & \\
\hline \multirow{8}{*}{ Group-2 } & 2 & \multirow{8}{*}{2562.26} & \multirow{8}{*}{2562} & \multirow{8}{*}{2705.08} & \multirow{8}{*}{2952.1} \\
\hline & 3 & & & & \\
\hline & 37 & & & & \\
\hline & 40 & & & & \\
\hline & 73 & & & & \\
\hline & 76 & & & & \\
\hline & 110 & & & & \\
\hline & 111 & & & & \\
\hline \multirow{4}{*}{ Group-3 } & 38 & \multirow{4}{*}{3137.86} & \multirow{4}{*}{3137.86} & \multirow{4}{*}{3137.86} & \multirow{4}{*}{3137.86} \\
\hline & 39 & & & & \\
\hline & 74 & & & & \\
\hline & 75 & & & & \\
\hline
\end{tabular}

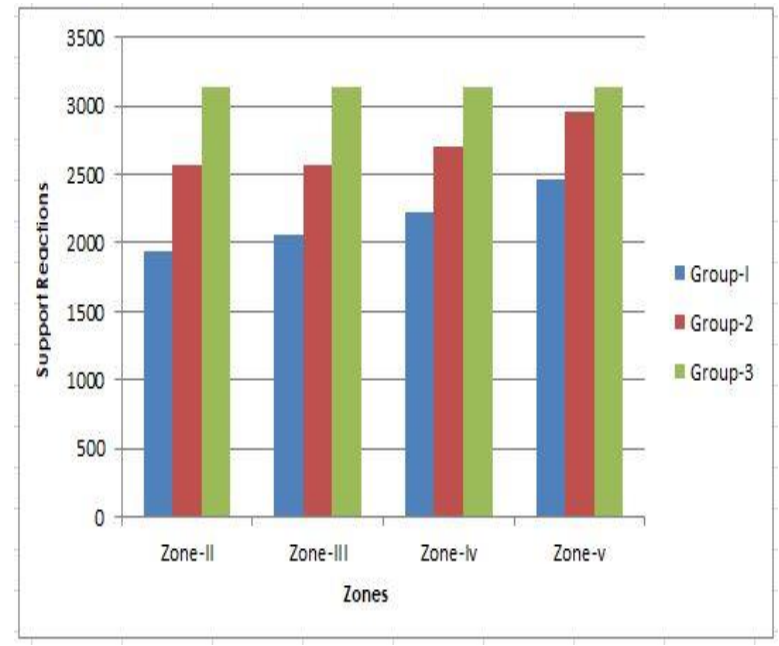

Figure 21. Zones - support reaction for Different seismic zones

\subsection{Steel Quantity variation}

Table 3. Steel Quantity Variation from zone to zone

\begin{tabular}{|c|c|}
\hline ZONES & STEEL(Tons) \\
\hline ZONE-II & 14.78 \\
\hline ZONE-III & 27.57 \\
\hline ZONE-IV & 29.36 \\
\hline ZONE-V & 32.02 \\
\hline
\end{tabular}




\section{E-ISSN: 2321-9637 \\ Available online at www.ijrat.org}

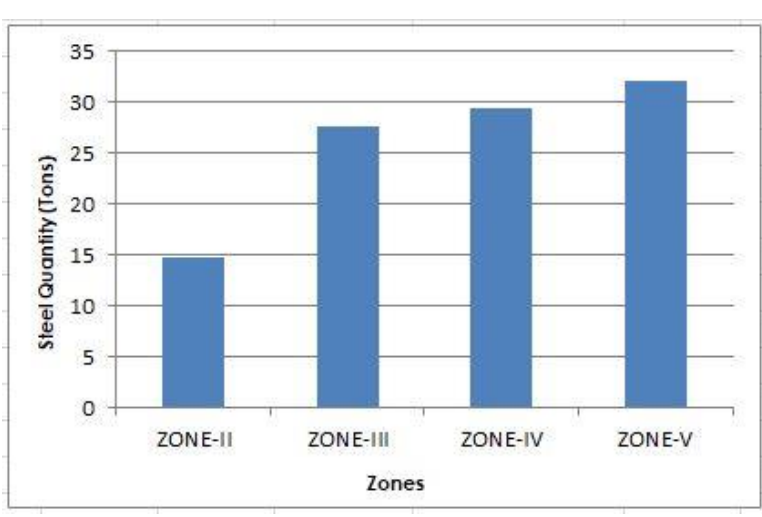

Figure 21. Zones - support reaction for Different seismic zones

\section{CONCLUSIONS}

1. The Structure analyzed in different seismic zones of India , than we find out the results in base shear of the building is more in seismic zone- $\mathrm{V}$ has compare to zone-II, zone-III and zone-IV.

2. Baseshear of seismic zone $\mathrm{V}$ is higher than $72.2 \%, 55.56 \%$ and $33.33 \%$ as compared to zoneII,zone-III,zone-IV respectively.

3. Coming to Floor Displacements zone-v as higher displacements than zone-II,zone-III and Zone-IV.

4. In Maximum Floor Displacements seismic zone$\mathrm{V}$ is higher than $39.79 \mathrm{~mm}, 30.77 \mathrm{~mm}, 18.52 \mathrm{~mm}$ as compared to zone-II,zone-III,zone-IV respectively.

5. Support reactions zone-V as higher value as compare to zone-II,zone-III,zone-IV.

6. Steel quantity of seismic zone- $\mathrm{V}$ is higher than $53.84 \%, 13.89 \%$ and $8.31 \%$ as compared to zoneII,zone-III and zone-IV.

7. From the above results zone-V is critical for the $\mathrm{G}+7$ structure.

8. seismic force acts on the structure it reflects additional force acting on the structure, Because of these addition forces structure behave different way than normal condition.

9. comes to seismic zones zone-v has higher zone factor than other zones.so zone-v values are more than as to compare other zones.

10. Base shear,Displacements,support reactions and steel quantity are Depends on zone factor,so these values are more in zone-v.

\section{REFERENCES}

[1] Mahmoud.SY,Abdallah,W.(2014).Response analysis of Multistorey Rc Building under Equivalent static and Dynamic Loads According to Egyptian code,2(1),79-88.

[2] RizawanSultan,M.GousepeeraD.(2015).Dynamic Analysis of Multistorey Building for Different shapes,8(2),85-91.
[3] Saikrishna.T,Srinivasarao.V.(2016).Earthquake analysis and Design of multistorey Building for Different seismic Zones in India,4(4),606-611.

[4] Venkatarao,Nagaraju.D.(2016).Time History Analysis of the Multistorey Building With and Without Masonry Structure and Shear wall for Variousseismiczones,International journal of Pure and Applied Mathematics,120(6),4305-4322.

[5] Satyanarayana.K.,VinodKumar.(2016).Seismic Response of Rc Frame Building with soft storey at Different Floor Levels.International Journal of Engineering Trends and Technology,42(4),201207.

[6] Bhandarkr.R,Ratanpara.M,Qureshi.M.(2017)Seis mic Analysis and Design of Multistorey Building using Etabs.Internation Journal of Engineering Developementand Rearch,5(2),78-90.

[7] Arvindkumar.G,AamirBaig.M.(2017).Compariso $\mathrm{n}$ and Analysis of Multistorey RCC Building in Different seismic zones.International Journal of Advanced Research,3(4),367-376

[8] Pawade.c,sakleshcha.P,Nikhar.R.(2018).Comparis on and analysis of regular and irregular configuration of multistorey building in various seismic zones and soil types.International Advanced Research Journal science,5(6),81-87.

[9] sylviya.B,Eswaramoorthi.P.(2018).Analysis of Rcc Building With Shear walls at Various Locations and In Different Seismic zones.International Journal of Innovovative Technology and Exploring Engineering,8(2s). 